\title{
PERFORMANCE IMPROVEMENT MODEL FOR CULINARY BUSINESS IN TASIKMALAYA
}

\author{
Irman Firmansyah $^{1^{*}}$, Nisa Noor Wahid ${ }^{2}$, and Adil Ridlo Fadillah ${ }^{3}$ \\ 1,2,3 Universitas Siliwangi, Indonesia
}

\begin{abstract}
This study aims to solve the problems that occur in the culinary business in Tasikmalaya which is currently easy to go out of business. Therefore it is necessary to find a useful model to solve the problem through testing the ability to prepare financial statements and managerial ability in improving the performance of SMES/MSMEs, especially on culinary business in Tasikmalaya. Through the research will be known the influence of the ability to prepare financial statements and managerial ability on performance, so that in the short term management will know how the benefits obtained if culinary entrepreneurs are ability to prepare financial statements well and improve managerial ability. The method used is through survey and analyzed using regression model through multiple regression analysis with the help of Smart PLS. The results showed that the ability to prepare financial statements has a positive effect on the performance of culinary business in Tasikmalaya City, managerial ability does not affect the performance of culinary business in Tasikmalaya City. Thus culinary business owners need the ability to prepare financial statements so that entrepreneurs are able to analyze the condition of their business through information generated from the financial statements.
\end{abstract}

Keywords: ability to prepare financial statements, managerial ability, performance

\section{INTRODUCTION}

Micro Small and Medium Enterprises (MSMEs) and Small Medium Enterprises (SMEs) in Indonesia is one of the powerful people of the people's economy, able to show its existence by staying survive in the face of changes in the business world since the monetary crisis that occurred in Indonesia in 1998 and continued with the global crisis in 2007-2008. According to Urata (2000) on the role of SMEs seen from his position as a major player in the economic activities of various sectors, the largest employer, an important player in the development of regional economic activities and community empowerment, creators of new markets and innovation, for SMEs who have gone international SME contributed to maintaining the balance of payments through its contribution to export.

In undertaking the Asean Economic Community (AEC) especially in 2018, SMEs in Indonesia should be able to improve competitiveness and quality of self and can capture every opportunity that exists to remain exist in the national and international economy. Including culinary SMEs in the City of Tasikmalaya which is currently getting a lot of competition with similar products both from other regions and from abroad with the presence of fast food and so forth. In addition, the current technological developments are

* Corresponding author. Email address: irmanfirmansyah@unsil.ac.id 
progressing very rapidly so that impact on all human activities, especially economic activity (Firmansyah \& Wahid, 2016).

In general, despite having a strategic role, developing the performance of SME/MSME is not an easy thing. Management issues, especially in financial management and the preparation of financial reports are very influential on the development of SME/MSME performance. However, the implementation of financial staement preparation on SME/MSME including culinary business in Tasikmalaya City is still very weak. This weakness is evidenced from the results of research Sukmana and Firmansyah (2014) which shows that the highest problem in the preparation of financial statements in accordance with the standard (SAK-ETAP) is due to unprofessional management and do not know SAK ETAP. This is due to low education and lack of understanding of Financial Accounting Standards and only focus on the work (Firmansyah \& Wahid, 2018) so that SMEs are still concurrently tasks in running their business in marketing, operations, managing human resources and finance as well as transactions are still simple .

Financial Statement is a tool of business condition picture (whether progress or setback), accurate and timely decision makers and responsibilities on management and most importantly is understanding the meaning of profit or loss derived from the results of his business. Therefore, financial statements are very useful for assessing business performance and can help in facing problems in running a business. So to achieve a good performance one way is to organize the preparation of good financial statements. However, the problem that occurs is that many culinary entrepreneurs only record the amount of money received/payed, the amount of raw materials purchased, goods sold, and the amount of accounts receivable or debt does not follow the guidelines in the preparation of the actual Financial Statement. This will make it difficult for them to measure and prove their business performance. Evidently many culinary entrepreneurs who easily folded. Whereas with the ability in preparing financial statements it can improve performance. This is evidenced by the results of research Whetyningtyas (2015) who conducted research on embroidery and convection entrepreneurs in the District Kudus said that the ability to prepare financial statements have a significant effect on SME operational performance. Although there are other studies that mention that the ability to prepare financial statements does not significantly affect the performance of SMEs (Harahap, 2014 and Nurlaela, 2015).

In addition, other factors that influence the operational performance of SMEs are managerial ability. Managerial ability is a process or activity that explains what managers do in their organization's operations to plan, organize, initiate, and control operations. According Hasibuan (2003) managerial ability is the ability or leadership skills to carry out management functions. In the field of management, the factor of managerial ability is very important and decisive, because these factors relate to the principal activity of an organization that is leading the organization concerned in an effort to achieve the goal. They plan by setting strategies, goals and choosing the best moving directions to achieve what is planned. Therefore, if the culinary businessman in Tasikmalaya has good managerial ability then it will be able to maintain its business even able to improve its performance. This is as described by Sumanto (2004) in the results of his research mentions that the managerial ability positively affect the 


\section{PERFORMANCE IMPROVEMENT MODEL FOR CULINARY BUSINESS IN TASIKMALAYA}

performance. Although there is still research that says that the managerial ability does not affect the performance of the business (Nurhasmansyah et al, 2015).

Therefore, based on the exposure and some research results above, in order to maintain and improve the performance of culinary business in Tasikmalaya City, the authors want to examine the model of performance improvement for culinary business in Tasikmalaya City.

\section{LITERATURE REVIEW}

2.1 Small Medium Enterprises

According to Law No. 20 Year 2008, the so-called Small Business is an entity that has the following criteria:

1. Net assets of more than Rp 50,000,000.00 (fifty million rupiah) up to a maximum of Rp 500,000,000.00 (five hundred million rupiah) excluding land and building of business premises; and

2. Having annual sales of more than Rp 300,000,000.00 (three hundred million rupiah) up to a maximum of $\operatorname{Rp} 2.500 .000 .000,00$ (two billion five hundred million rupiah).

While Medium Enterprises is a business entity that has the following criteria:

1. Net assets of more than Rp 500,000,000.00 (five hundred million rupiah) up to a maximum of Rp 10,000,000,000.00 (ten billion rupiah) excluding land and building of business premises; and

2. Having annual proceeds of more than Rp2,500,000,000.00 (two billion five hundred million rupiah) up to a maximum of Rp 50,000,000,000.00 (fifty billion rupiahs).

Some Characteristics of Small Business are as follows:

1. The type of goods or commodities cultivated are generally not easy to change;

2. The location / place of business is generally settled not to move;

3. In general already doing financial administration though still simple, corporate finance has begun to be separated with family finances, has made a balance sheet of business;

4. Already have business license and other legality requirements including NPWP;

5. Human resources (entrepreneurs) have experience in business entrepreneurship;

6. Some have access to banking in the case of capital requirements;

7. Most have not been able to make good business management such as business planning.

While the criteria of Medium Enterprises are as follows:

1. In general, have better management and organization, more regularly even more modern, with a clear division of tasks, among others, the financial, marketing and production sections;

2. Conducting financial management by applying the accounting system regularly, making it easier for auditing and assessment or examination including by banking;

3. Have done the rules or management and labor organization, there has been Jamsostek, health care etc; 
4. Already have all the legality requirements such as permit neighbors, business permits, place permits, NPWP, environmental management efforts etc;

5. Already access to banking funding sources;

6. Generally have trained human resources. (Suhardjono, 2003: 33)

\subsection{Business Performance}

Harahap (2014) explains that the operational performance is all the work obtained from all business activities in certain periods to realize the goals of the organization or company. Performance in organizations or businesses, can be grouped on strategic performance, administrative performance and operational performance. Strategic performance is typically associated with strategies in strategic policy adjustment in the hands of top managers because it involves the strategy of dealing with outsiders, as well as strategic performance should be able to create a vision for the future about the macroeconomic conditions of the country that affect the sustainability of the organization; Administrative performance relates to the performance of the administration of the organization, including the administrative structure governing the authority relations (authority) and the responsibilities of the person occupying the position or working on the units within the organization. In addition, administrative performance is related to the performance of the information flow mechanism among work units within the organization, in order to achieve synchronization of work between work units; Operational performance is related to the effectiveness of the use of each resource used by the organization. The ability to achieve the effectiveness of the use of resources (capital, raw materials, technology and others) depends on the human resources that do.

Business performance measured in this study is the operational performance which is all the work obtained from all business activities in certain periods to realize the goals of the organization or company. So this becomes important especially in conducting an assessment of operational performance of Culinary Business of Tasikmalaya City. For more details here are the operational performance indicators:

- Ability to Increase Selling

- Ability to Increase Customers

- No Difficulty Restoring Credit

- Able to Increase Profits

- Able to Develop Capital

- More careful in taking a decision

- Faster in Reading Opportunities

\subsection{Ability to Prepare Financial Statements}

Financial Statements is basically the result of an accounting process that can be used as a tool to communicate between financial data or activities of a company with parties concerned with data or activities of the company. According to the Indonesian Institute of Accountants (2015) the financial statements are part of the financial reporting process, usually including the statement of financial position, income statement, cash flow statement or fund flow statement), other records and reports and explanatory materials that are an integral part of the financial statements . An entrepreneur must periodically know the financial position as well as the results of his company's operations, 


\section{PERFORMANCE IMPROVEMENT MODEL FOR CULINARY BUSINESS IN TASIKMALAYA}

know the source and use of the funds obtained, plan and make corrective decisions. For that, required a Financial Report for his business.

Accounting information has an important role to achieve business success, including for small businesses (Magginson et al., 2000). Accounting information can be a reliable basis for economic decision making in small business management, including market development decisions, pricing and more. Provision of accounting information for small businesses is also needed, especially for access to government subsidies and additional capital access for small businesses from creditors (Banks).

Ability to prepare financial statements owned by SME actors in this research is more emphasized on intellectual ability. Intellectual ability is the ability needed to perform various mental activities, thinking, reasoning, and solving problems (Robbins, 2008: 56-66). The intellectual ability possessed by a person shows a person's level of intelligence so that the person will be easier in solving problems during work, faster developing self-ability and finally able to do the job well. So with the intellectual ability, a businessman SMEs can prepare financial reports well, which ultimately the performance of SME increased.

The following indicators of intellectual ability according to Robbins (2008):

1. Numerical Intelligence: the ability to calculate quickly and precisely.

2. Verbal Understanding: the ability to understand what is being read and heard.

3. Perceptual Speed: the ability to recognize similarities and visual differences quickly and precisely.

4. Inductive reasoning: the ability to recognize a logical sequence in a problem and then solve that problem.

5. Deductive reasoning: the ability to use logic and assess the implications of an argument.

6. Space Visualization: the ability to imagine how an object will appear if its position in space is changed.

7. Memory: the ability to hold back and recall past experiences.

The better someone in preparing the financial statements will improve performance because if someone is able to know the financial condition of the company so soon will be the evaluation material to continue to increase profits business. The existence of the influence between the ability of preparing financial statements on the performance has been proven by the research results Whetyningtyas (2015) who conducted research on embroidery and convection entrepreneurs in the District Kudus said that the ability to prepare financial statements have a significant influence on SME operational performance. Therefore the first hypothesis proposed in this study are:

H1: Ability to prepare financial statements has a positive effect on the performance of culinary business in Tasikmalaya City

\subsection{Managerial Ability}

Managerial is the application of economic theory and decision science analysis tools to discuss how an organization can achieve its goals or intentions in an efficient way. According Tangkilisan (2005: 10) managerial ability is the 
ability to utilize and mobilize resources to be driven and directed to the achievement of goals through the activities of others. To be able to achieve the goals that have been determined then the leadership or entrepreneur of a company must have the ability to implement management principles commonly known as managerial ability.

Meanwhile, according to Winardi (1995: 4) in Setyanusa, (2009), states that "Managerial ability is the ability to take action planning, organizing, implementation, supervision conducted to achieve the target set".

As for some indicators of managerial ability are as follows:

1. Planning

2. Organizing

3. Supervision

4. Assessment

If these indicators of managerial ability are well done to the company, it will improve the quality of the business and will ultimately improve its operational performance. Therefore, there is a link between managerial ability and business performance. The better the managerial performance will lead to an increase in operational performance. This has been proven by Sumanto (2004) in the results of his research mentions that the managerial ability positively affect the performance. So the second hypothesis proposed in this study are:

H2: Managerial ability has a positive effect on culinary business performance in Tasikmalaya City

\section{RESEARCH METHOD}

Referring to the characteristics of the research, the method used in this study is survey and explanatory, because this research is included in survey research using a quantitative approach framework. This approach aims to collect data from a number of cases and measure the symptoms that exist. In this study, information collected from the respondents through the use of questionnaires with the unit of analysis is the culinary business in Tasikmalaya City.

\subsection{Population and Sample}

The population in this research is all the culinary business in Tasikmalaya City which is joined with Tasikmalaya Culinary Community (KWKT) which is 483 entrepreneurs. Of the existing population, the samples taken using the Slovin formula. This method is used to simplify the data collection and has been widely used. The number of samples according to the Slovin formula are:

$$
\mathrm{n}=\mathrm{N}
$$

where:

$$
\begin{array}{ll}
\mathrm{n} & =\text { sample size } \\
\mathrm{N} & =\text { population size } \\
\mathrm{e} & =\% \text { leniency inaccuracy due to sampling error } \\
\text { so the number of samples are: }
\end{array}
$$




$$
\begin{aligned}
& \text { n }=\text {------------------- } \\
& 483 \\
& =\text {------------ }=82,85 \text { rounded of }=83 \text { samples }
\end{aligned}
$$

So that the number of samples to be studied are 83 culinary entrepreneurs in Tasikmalaya City.

\subsection{Operationalization Variables}

Variables in this study consists of independent variables that is the ability to prepare financial statements and managerial ability. Dependent variable is operational performance. For more details the variables in this study are as follows:

Table 1 Operationalization of Research Variables

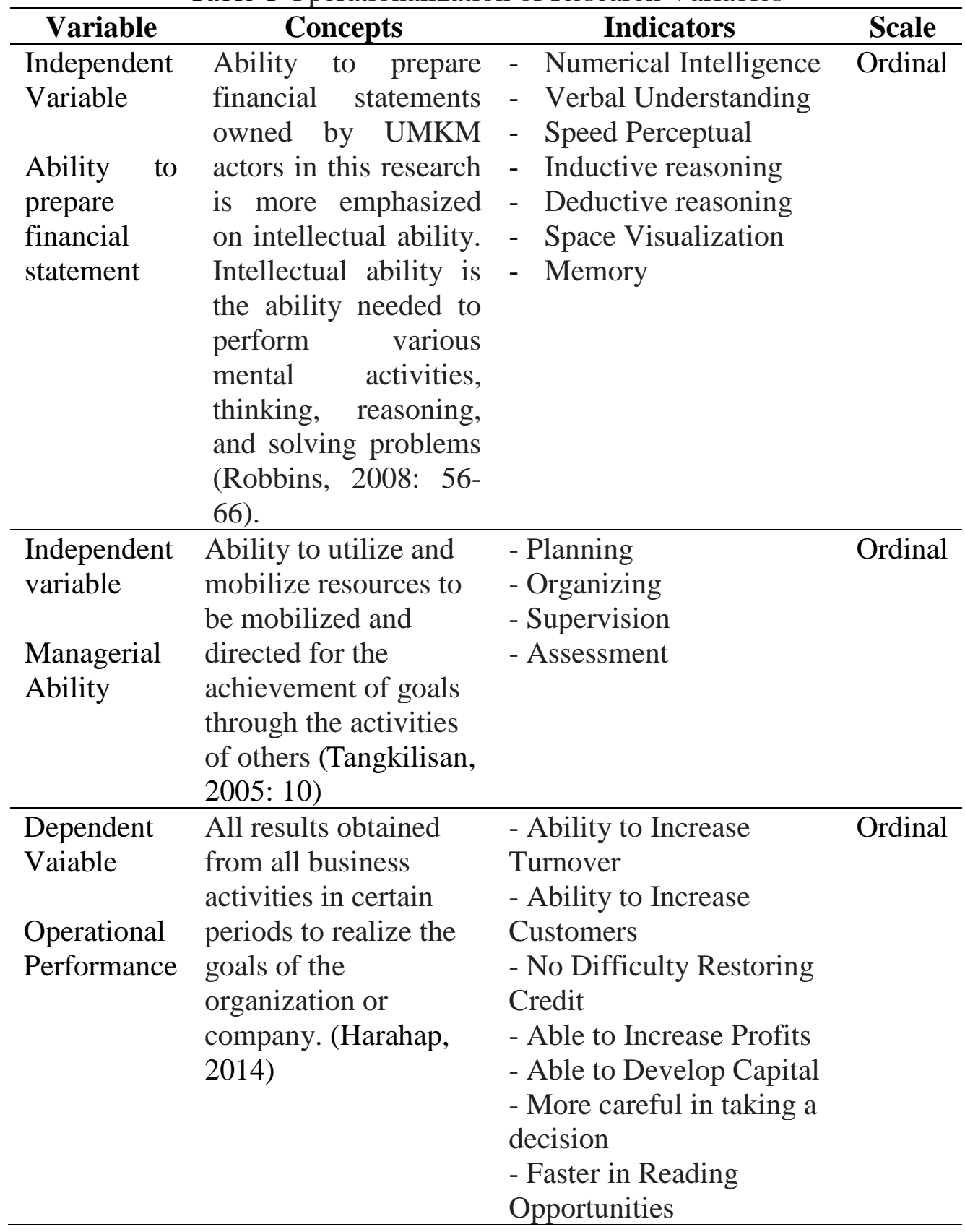




\subsection{Analysis Technique}

To measure the effect of the ability to prepare financial statements and managerial ability on operational performance, multiple linear regression is used with the formula:

$$
\mathrm{OP}=\mathrm{a}+\mathrm{b}_{1} \mathrm{AFS}_{1}+\mathrm{b}_{2} \mathrm{MA}_{2}
$$

where:

$$
\begin{array}{ll}
\text { OP } & =\text { Operational Performace } \\
\mathrm{a} & =\text { Constanta } \\
\mathrm{b}_{1,2} & =\text { Coefficient Regresion } \\
\text { AFS } & =\text { Ability to Prepare Financial Statement } \\
\text { MA } & =\text { Managerial Ability }
\end{array}
$$

In performing data analysis, then data processing using SmartPLS 3 program.

\section{RESULT AND DISCUSSION}

\subsection{RESULT}

The spread of questionnaires conducted during March to May 2018 through two ways, namely, conducted by the researchers themselves by making direct visits to all places of business that became the object of research, and through visits to the exhibition. In this study the authors divide the characteristics of respondents based on position positions, gender, educational background, education level and length of work in the current position. It is intended that in conducting the research get a sample description of the respondents in answering the research questionnaire.

Table 2 Respondent Characteristics

\begin{tabular}{clcc}
\hline & Categories & Amount & Percentage \\
\hline $\begin{array}{c}\text { Age of } \\
\text { business }\end{array}$ & \multicolumn{1}{c}{$\quad$ 5 years years $<\ldots<10$} & 52 & 62,65 \\
& \multicolumn{1}{c}{ years } & 24 & 28,92 \\
& $\quad$ 10 years $<\ldots$ & 7 & 8,43 \\
& Total & $\mathbf{8 3}$ & $\mathbf{1 0 0 , 0 0}$ \\
\hline Education & High School & 17 & 20,48 \\
& Diploma & 13 & 15,66 \\
& Bachelor & 44 & 53,01 \\
& Master & 9 & 10,84 \\
& Total & $\mathbf{8 3}$ & $\mathbf{1 0 0 , 0 0}$ \\
\hline Age of & $<20$ years & 14 & 16,87 \\
Owner & 20 years $<\ldots<30$ & & 26,51 \\
& years & 22 & \\
& 30 years $<\ldots<40$ & & 39,76 \\
& years & 33 & 16,87 \\
& 20 years $>$ & 14 & $\mathbf{1 0 0 , 0 0}$ \\
\hline & Total & $\mathbf{8 3}$ & \\
\hline
\end{tabular}

From table 2 above we can see that the respondents in this study who have a business duration of less than 5 years are as many as 52 people or 
$62.65 \%$, have a business length of 5 to 10 years as many as 24 people or $28.92 \%$ and who have a long business more than 10 years as many as 7 people or $8.43 \%$. While respondents who have high school education is as many as 17 people or $20.48 \%$, who have D3 education is 13 people or $15.66 \%$, who have S1 education is as many as 44 people or $53.01 \%$ and who have $\mathrm{S} 2$ education as much as 9 person or $10.84 \%$. So the average of the majority of entrepreneurs is Bachelor. Furthermore, respondents who have age below 20 years are as many as 14 people or $16.87 \%$, who have ages 20 to 30 years as many as 22 people or $26.51 \%$, who have ages 30 to 40 years as many as 33 people or $39.76 \%$ and who have age above 40 years as many as 14 people or $16,87 \%$. So that the majority of respondents are entrepreneurs aged 30 to 40 years.

\subsubsection{Evaluation of Outer Model}

The Outer model specifies the relationship between the latent variable and its indicator or manifest variable. The Outer model defines how each indicator block corresponds to its latent variable. Here is an initial model image that is processed using Smart PLS 3.0 application.

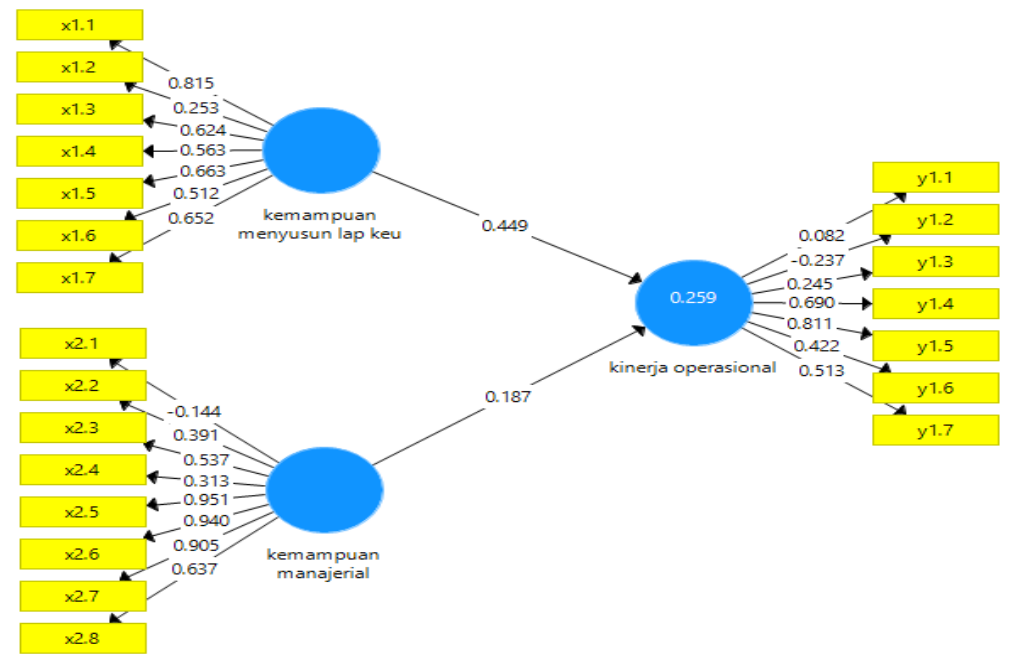

Figure 1 Output PLS (Loading Factor)

\section{a. Convergent Validity}

Model evaluation can be done using convergent validity on the reflexive model by looking at factor loading values. The loading factor values vary but some experts suggest above 0.4 by looking at the outer loading values. In this study the indicator on each variable is not all declared valid because there is still an indicator value less than 0.4 , so researchers first remove the invalid indicator so that the new model is produced. 


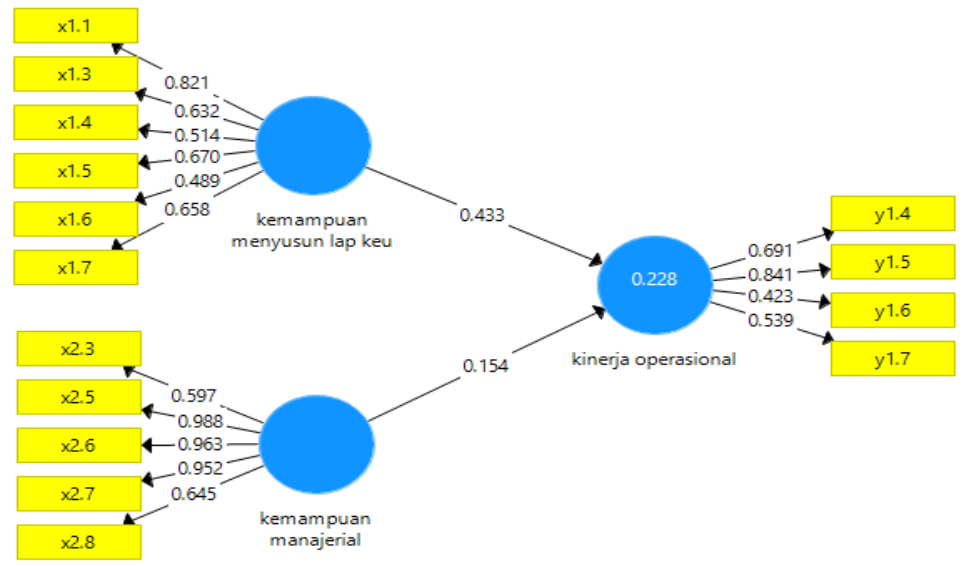

Figure 2 Output PLS (Loading Factor) Revision

According to the provisions, the value of AVE should be above 0.5 so that in this study has fulfilled the requirement that the indicator is valid. However, if there is an AVE value above 0.4, then the Average Variance Extracted (AVE) value can still be considered.

Composite reability measures internal consistency and its value should be above 0.7. The table below explains that this study is in compliance with the Composite reability value standard because it is $>0.7$.

Reability test reinforced with cronbach alpha where expected value $>0.7$ for all constructs. The table below explains that this study is in accordance with the standard value of cronbach alpha because its value> 0.7 .

Table 3 Evaluation of Outer Model

\begin{tabular}{lccc}
\hline \multicolumn{1}{c}{ Variables } & $\begin{array}{c}\text { Average Variance } \\
\text { Extracted (AVE) }\end{array}$ & $\begin{array}{c}\text { Composit } \\
\text { Reliable }\end{array}$ & $\begin{array}{c}\text { Cronbach's } \\
\text { Alpha }\end{array}$ \\
\hline $\begin{array}{l}\text { Ability to prepare } \\
\text { financial statement }\end{array}$ & 0.717 & 0.924 & 0.898 \\
Managerial ability & 0.410 & 0.802 & 0.748 \\
Operational performance & 0.414 & 0.726 & 0.745 \\
\hline
\end{tabular}

\section{Source: Output SmartPLS}

\subsubsection{Evaluation of Inner Model}

Inner model specifies the relationship between latent variables (structural model) which describes the relationship between latent variables based on substantive theory. 


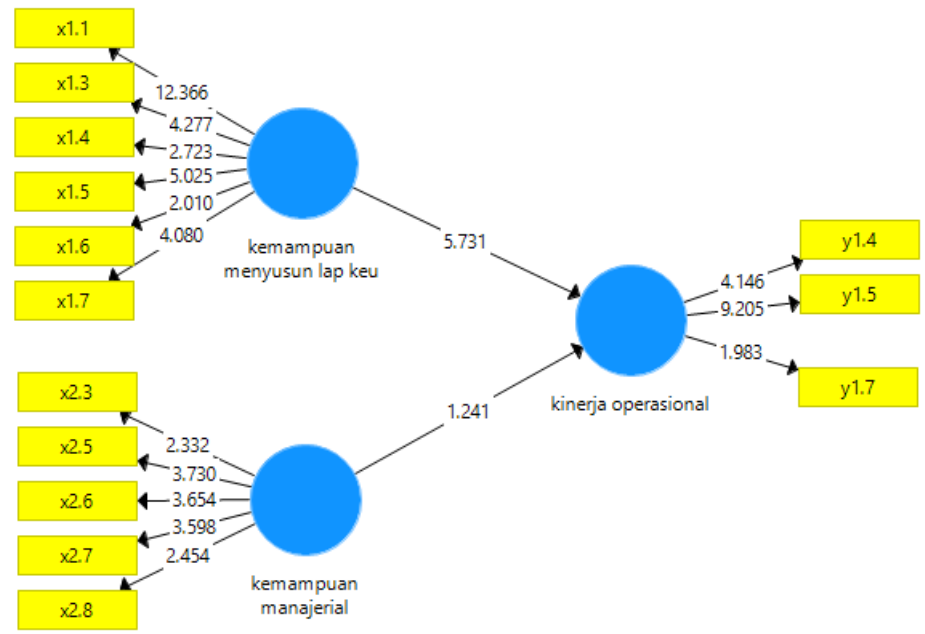

Figure 3 Output PLS (t-test)

a. R-Square

It is the coefficient of determination in the endogenous constructs described in the table below.

\begin{tabular}{lr}
\multicolumn{2}{c}{ Table 4 Evaluation of R-Square } \\
\hline \multicolumn{1}{c}{ Variables } & $\boldsymbol{R}$ Square \\
\hline Ability to prepare financial statement & 0 \\
Managerial ability & 0 \\
Operational performance & 0,228 \\
\hline \multicolumn{2}{c}{ Source: Output SmartPLS }
\end{tabular}

Based on table 4 can be explained that business performance can be influenced by the ability to prepare financial statements and managerial ability of $22.8 \%$. While the rest of $77.2 \%$ influenced by other factors that are not researched.

b. Test of Hypotesis

Hypothesis testing in this study by looking at the results of data processing in the Path Coefficients section as in table 5 below.

Table 5 Path Coefficients

\begin{tabular}{|c|c|c|c|c|}
\hline Relationship between variables & $\begin{array}{c}\text { Original } \\
\text { Sample }(\mathbf{O})\end{array}$ & T statistik & P value & Conclussion \\
\hline $\begin{array}{llr}\text { Ability to } & \text { prepare } & \text { financial } \\
\text { statement } & -> & \text { operational } \\
\text { performance } & & \end{array}$ & 0.438 & 5.731 & 0.000 & Significant \\
\hline $\begin{array}{l}\text { Managerial Ability -> operational } \\
\text { performance }\end{array}$ & 0.144 & 1.241 & 0.215 & $\begin{array}{c}\text { Not } \\
\text { Significant }\end{array}$ \\
\hline
\end{tabular}

\section{Source: Output SmartPLS}

Based on table 5, it is explained that the ability to prepare financial statements affect the operational performance, $t$ count of 5.731 (greater than 1.96) so that the first hypothesis accepted. Managerial ability does not affect the 
operational performance, $t$ count of 1.144 (smaller than 1.96) so that the second hypothesis is rejected.

\subsection{Discussions}

The results of this study indicate that the ability to prepare financial statements has a significant effect on operational performance. These results prove that accounting information generated from the process of preparation of financial statements is an important part in running the company's operations, especially in the culinary business sector. Information generated from the financial statements will provide important information as it will provide an explanation of the company's assets including debt and net worth. In addition, through the financial statements will be informed of its performance in the form of profit generated. Thus the business owner will make the policy through the evaluation made from the financial statements and strategies in order to improve business performance. Therefore this research shows that a culinary entrepreneur who has the ability in preparing financial statements will facilitate in improving business performance. Through this research shows that the financial statements will give a significant effect to the improvement of business performance, especially on the culinary business in Tasikmalaya. Success in current business competition will be reflected through the financial statements if the owner of the company is able to prepare financial statements well. This result is in accordance with the research of Whetyningtyas (2015) who conducted research on embroidery and convection entrepreneurs in Kudus District mentioned that the ability of preparing financial statements has a significant influence on the operational performance of SMEs.

In addition, the results of this study also found that managerial ability does not affect the operational performance. These findings indicate that a business leader in running his business will exert all his ability in managing his efforts to achieve good performance. Policies, strategies, implementation and supervision made in order to obtain maximum results. But all the activities he did not improve the performance of his business. This of course becomes a finding that gives enough picture that managerial ability certainly not enough be base to improve its performance. Management should not forget important information related to policy making. One such information is in the financial information presented on the good financial statements.

Company management must has a basic footing in making decisions, especially financial information that describes the condition of the company. So the ability of a person in running his business will not necessarily get a good performance if not see the financial information generated. The results of this study is certainly not in line with the results of research Sumanto (2004) in his research that mentions that the managerial ability positively affect the performance.

\section{CONCLUSSIONS AND SUGGESTIONS}

Based on the results of analysis and discussion, it can be concluded as follows:

1. The ability to prepare financial statements has a positive effect on the performance of the culinary business in Tasikmalaya City. This shows that entrepreneurs who have the ability to prepare financial statements will certainly be better in improving business performance. 


\section{PERFORMANCE IMPROVEMENT MODEL FOR CULINARY BUSINESS IN \\ TASIKMALAYA}

2. Managerial ability does not affect the performance of culinary business in Tasikmalaya City. This shows that the managerial ability is not enough capable in order to improve business performance, because there are important things that must be considered by the leadership as the basis of business policy.

In addition, the authors provide suggestions that are expected to provide benefits to the parties in need. The suggestions are as follows:

1. For the culinary business owner in Tasikmalaya City in particular, it is necessary to increase the capability in preparing financial statements. This is important because as a basis for policy making on the business it is running.

2. In the case of lack of knowledge in preparing financial statements, it is necessary training from government or from educational institutions.

3. For further research, the researcher will add variable research, location and object of research in order to found new model in finding factors influencing business performance especially SME sector.

\section{References}

Firmansyah, I., \& Wahid, N.N. (2016). Analisis Model Marketing Kelom Geulis dengan Metode AHP di Kota Tasikmalaya. Jurnal Ekonomi dan Bisnis. 10(2), 121-129

. (2018). Akuntansi Counter Pulsa dan Handphone. Tasikmalaya: LPPM Universitas Siliwangi

Harahap, Y. R. (2014). Kemampuan Menyusun Laporan Keuangan Yang Dimiliki Pelaku UKM Dan Pengaruhnya Tehadap Kinerja UKM. Jurnal Riset Akuntansi dan Bisnis. 14(1)

Ikatan Akuntan Indonesia. (2015), Standar Akuntansi Keuangan (SAK). Jakarta

Megginson, L. C., Byrd, M. J., \& Megginson, W. L. (2000). Small Business Management: An Entrepreneur's Guidebook. Third Ed. Irwin Mc Graw-Hill. Boston

Nurhasmansyah., Zulfadil., \& Machasin. (2014). Pengaruh Latar Belakang Sosial, Kemampuan Manajerial Dan Pengalaman Terhadap Kinerja Usaha (Studi Empiris Pada Industri Kecil Menengah Pengrajin Di Kota Batam). Jurnal Tepak Manajemen Bisnis. 6(1)

Nurlaela, S. (2015). Kemampuan Menyusun Laporan Keuangan Usaha Kecil Menengah Pengaruhnya terhadap Kinerja UKM Kerajinan Gitar di Kabupaten Sukoharjo. Jurnal Paradigma. 12(2)

Robbins, S. P., \& Judge, T. A. (2008). Perilaku Organisasi. Buku 1 dan 2. Jakarta: Salemba Empat

Suhardjono. (2003). Manajemen Perkreditan UKM, Yogyakarta: AMP YKPN

Sukardi. (2004). Metodologi Penelitian Pendidikan . Jakarta. Bumi Aksara

Sukmana, W., \& Firmansyah, I. (2014). Aplikasi Analytic Network Process dalam Mengurai Masalah Penerapan Standar Akuntansi Keuangan 
ETAP pada Usaha Kecil Menengah di Jawa Barat. Jurnal Akuntansi dan Manajemen. 25(1)

Sumanto. (2004). Pengaruh Kemampuan Manajerial, Gaya Kepemimpinan dan Motivasi Kepala Sekolah Terhadap Kinerja Guru di MTsN Plupuh Kabupaten Sragen. Tesis Magister Manajemen, UMS Surakarta

Tangkilisan, H. N. S. (2005). Dasar-Dasar Manajemen. Jakarta: Liberty

Urata, S. (2000), Policy Recommendation for SME Promotion in the Republik of Indonesia, JICA, Tokyo

Undang-Undang No 20 Tahun 2008.

Whettynigtyas, A. (2105). Analisis Pengaruh Kemampuan Menyusun Laporan Keuangan dan Jiwa Kewirausahaan terhadap Kinerja Operasional UMKM. Prosiding Seminar Nasional dan Call For Paper 2015. Optimalisasi Peran Industri Kreatif dalam Menghadapi Masyarakat Ekonomi ASEAN. FEB Univ. 17 Agustus 1945 Semarang 